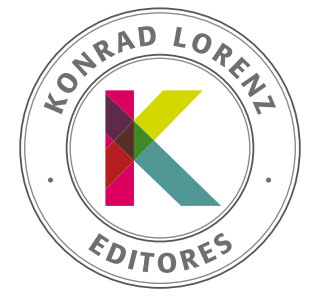

\title{
Validation of the Self-Curiosity Attitude-Interest Scale in Colombia
}

\author{
Ilaria Durosini ${ }^{\mathrm{a}}$, Francesca Fantini ${ }^{\mathrm{b}}$, Carlos David Escobar Ramírez ${ }^{\mathrm{c}}$, \\ Angélica María Ríos Rodríguez ${ }^{\mathrm{d}}$, Maria Fernanda Jaramillo Richter \\ y Filippo Aschierif,*
}

\author{
a Department of Psychology, Università Cattolica del Sacro Cuore, Milano, Italy \\ ${ }^{b}$ European Center for Therapeutic Assessment, Università Cattolica del Sacro Cuore, Milano, Italy \\ c Private practice, Bogotá, Colombia \\ ¿ Universidad de la Sabana, Bogotá, Colombia \\ e Private practice, Bogotá, Colombia \\ f European Center for Therapeutic Assessment, Università Cattolica del Sacro Cuore, Milano, Italy
}

Received 15 February 2017; accepted 27 November 2017

\author{
KEYWORDS \\ self-curiosity, \\ curiosity, validation, \\ psychological \\ assessment
}

\begin{abstract}
This paper presents a theoretical review of the psychological construct of human curiosity and the Colombian version of the Self-Curiosity Attitude-Interest Scale. This is a two-factor self-report scale that assesses the attitude and the interest that people have to explore their own inner world. Two paired samples for gender, age and working class of Colombian $(n=170)$ and Italian $(n=195)$ participants $(N=365)$ were included in the study. Confirmatory Factor Analysis revealed a good fit of the data to the two-factor model of the Self-Curiosity Attitude-Interest Scale in Italian and Colombian subjects (respectively, $\chi^{2}(13)=16.073, p=.245$ and $\left.\chi^{2}(13)=10.352, p=.665\right)$. Also, Measurement Invariance Analysis suggested equivalent factor structures (Configural Invariance, $\chi^{2}(26)=26.423, p=.440$ ) and factor loadings across the two groups (Metric Invariance, $\chi^{2}(31)=34.242, p=.315$ ). The results do not support scalar invariance $\left(\chi^{2}(38)=82.058, p<.001\right)$. Data suggest concurrent validity of the Self-Curiosity Attitude-Interest in the Colombian group, welding evidence for the scale application in the Colombian context. In conclusion, the results posit that the two-factor model of the Self-Curiosity Attitude-Interest Scale is adequate in Colombia; the psychological construct of self-curiosity is conceived similarly in Colombia and in Italy, and the scale has expected correlations with other relevant psychological constructs.

(c) 2018 Fundación Universitaria Konrad Lorenz. Este es un artículo Open Access bajo la licencia CC BY-NC-ND (http://creativecommons.org/licenses/bync-nd/4.0/).
\end{abstract}

\footnotetext{
* Corresponding author.
}

E-mail address: filippo.aschieri@unicatt.it 


\author{
PALABRAS CLAVE \\ curiosidad sobre sí \\ mismo, curiosidad, \\ validación, \\ evaluación psicológica
}

\section{Validación de la Escala de Self-Curiosity Attitude-Interest en Colombia}

Resumen El objetivo de este estudio es presentar una revisión teórica del constructo psicológico de la curiosidad humana, así como presentar la validación de la versión colombiana de la Self-Curiosity Attitude-Interest Scale, una escala de auto-reporte de dos factores que evalúa la actitud y el interés que la gente posee para explorar su propio mundo interior. Se incluyeron en el estudio participantes $(N=365)$ Colombianos $(n=170)$ e Italianos $(n=195)$ pareados por género, edad y clase trabajadora. El Análisis Factorial Confirmatorio ha revelado un buen ajuste de los datos al modelo de dos factores de Self-Curiosity Attitude-Interest Scale en participantes italianos y colombianos (respectivamente, $\chi^{2}(13)=16.073, p=.245$ y $\chi^{2}(13)$ $=10.352, p=.665$ ). El Análisis de Invariancia ha sugerido factores de estructuras (Invariancia de Configuración, $\chi^{2}(26)=26.423, p=.440$ ) y pesos de los factores equivalentes entre los dos grupos (Invariancia Métrica, $\left.\chi^{2}(31)=34.242, p=.315\right)$. Los datos no soportan la Invariancia Escalar $\left(\chi^{2}(38)=82.058, p<.001\right)$. Adicionalmente, los datos destacaron la validez concurrente de la escala en el grupo de Colombia, y la posibilidad de aplicar la escala en el contexto colombiano. En conclusión, los resultados demuestran que el modelo de dos factores de la Self-Curiosity Attitude-Interest Scale es apto para ser aplicado en Colombia, así mismo reflejan que el concepto psicológico de la self-curiosity es concebido de forma similar tanto en Colombia como en Italia, y que la escala indica correlaciones con otras construcciones psicológicas relevantes.

(C) 2018 Fundación Universitaria Konrad Lorenz. This is an open access article under the CC BY-NCND license (http://creativecommons.org/licenses/bync-nd/4.0/).
Latin-American researchers showed that curiosity has an important role in different areas of psychology. In school psychology, curiosity is considered crucial to develop students' critical thinking, a scientific attitude (Sánchez, 2007), and to grow the desire to increase personal knowledge (Lopez \& Snyder, 2009). In clinical psychology, curiosity prevents the development of personality disorders (Sánchez, Méndez, \& Garber, 2009; Wanden-Berghe, Sanz-Valero, \& Wanden-Berghe, 2011). In social psychology, curiosity relates to the motivation of trying new behaviors and have new experiences with peers (Arango \& Vanegas, 2014; García \& Valdez, 2017; Trujillo \& Flòrez, 2013). Whilst curiosity has clear practical relevance, and can be generally considered as the desire to acquire new information about the world by learning new information through exploratory behavior (Berlyne, 1949, 1950, 1954, 1960; Loewenstein, 1994; Spielberger \& Starr, 1994), researchers have alternated during time between different theoretical conceptions to account for its mechanisms of action. On the one hand, authors dealing with curiosity saw it as an unpleasant emotional state trigged by novel, ambiguous, or complex stimuli. In this line, people manifest an increasing desire to acquire new information through exploratory behavior in order to reduce cognitive and perceptual incoherence (Berlyne, 1954; Dember, 1956; Harlow, 1950). However, this stance could not explain why people search situations that actually stimulate their curiosity (Berlyne, 1966; Fowler, 1966; Hebb, 1955). Hence, other theorists suggested that people are motivated to maintain an optimal level of arousal (Berlyne, 1967; Hebb, 1955; Leuba, 1955), balancing anxiety for the unknown with the pleasure for new discoveries. Thus, the so called "optimal arousal model" stressed the multidimensionality of the construct of curiosity. In recent years, Litman and colleagues (Litman, 2005; Litman \& Jimerson, 2004; Litman \& Silvia, 2006) showed that curiosity could be the outcome of both feelings of interest and of feelings of deprivation, while Kashdan and Fincham (2004) highlighted both a dispositional trait-feature and a situational-state kind of curiosity.

Recently, - prompted by the crucial role of clients' curiosity about themselves in Therapeutic Assessment (Finn, 2007)a brief intervention in which psychological tests are used to address clients' questions about themselves (Aschieri, De Saeger, \& Durosini, 2015), Aschieri and Durosini (2015) focused on a facet of curiosity, self-curiosity, defined as the disposition that people have to explore their inner world and the interest in understanding oneself better. Aschieri and Durosini developed the Self-Curiosity Attitude-Interest Scale (SCAI), a Likert-type scale that assesses the way in which people discover new aspects of their psychological functioning. This scale explores the individual differences in curiosity about self through two positively correlated dimensions $(r=.42)$ : the first factor, Attitude toward Self-Curiosity, refers to the attitude that people have to explore own inner world; the second factor, Interest in Increasing Knowledge of Self, refers to the interest that people have about new aspects of themselves (Aschieri \& Durosini, 2015). In the aforementioned study, the SCAI scale showed temporal stability in a four months' retest $(r=.78, p<.001)$, convergent validity with self-reflection $(r=.55, p<.001)$, openness to experience $(r=.35, p<.001)$, extraversion and agreeableness (respectively, $r=.20$ and .19, $p<.05)$. Self-curiosity correlated also with a widely measure of general curiosity $(r=.30, p<.001)$, suggesting that while the nomological network of self-curiosity included conceptually related variables, self-curiosity is still a specific and distinct construct. A follow-up study (Aschieri, Durosini, Locatelli, Gennari, \& Smith, 2016) showed Configural, Metric and Scalar Invariance of the SCAI in a cross-sectional study involving people with different levels of fluid intelligence, and no correlations between self-curiosity and intelligence $\beta=.06, p=.20)$. Aschieri and Durosini (2015) and Aschieri et al. (2016) also found acceptable coefficients of internal consistency for the full scale, particularly given the scale's 7-item length ( $\alpha=.65$ and $\alpha=.72$, respectively).

To date no studies have been carried out on the psychological construct of self-curiosity in Colombia. The relevance of testing a new measure in different countries allows the cross-cultural comparisons of subjects in those countries and eventually the development of increasingly universal laws of psychological functioning (Matsumoto, 2001). To this aim, this manuscript provides data on the validity of the Colombian version of the SCAI (Aschieri \& Durosini, 2015). 
Specifically, we assess the two-factor structure of the SCAI Scale in Colombia following a typical cross-cultural scale adaptation process and recommended statistical procedures (Beaton, Bombardier, Guillemin, \& Ferraz, 2000; Gálvez-Nieto, Salvo, Pérez-Luco, Hederich, \& Trizano-Hermosilla, 2017; Gómez-Lugo et al., 2016; Ruiz, Rosado, \& Galisteo, 2015; Soler et al., 2016; Vallejo-Medina et al., 2016; Van de Vijver, 2001) hence through Confirmatory Factor Analysis (CFA) and Measurement Invariance Analysis (MI). Also, the scale reliability and the construct validity were evaluated, correlating the SCAI with other conceptually related scales already valid for use in Colombia or Latin American countries.

\section{Method}

\section{Participants}

A convenience sample of 365 subjects participated in this study: 170 were Colombian (female $=114$; male $=56 ; M_{\text {age }}$ 30.13; $S D=11.93$ ) and 195 were Italian (female = 125; male = $\left.70 ; M_{\text {age }}=29.48 ; S D=10.31\right)$. The two sub-samples showed no differences for gender $\left(\chi^{2}(1)=.35, p=.553\right)$, age $\left(\chi^{2}(3)=5.77\right.$, $p=.124)$, and work $\left(\chi^{2}(2)=3.94, p=.140\right)$. Participants were recruited through psychology blogs, commercial mailing lists, and social networks. All the socio-demographic data are displayed in Table 1.

\section{Procedure}

Three native interpreters performed a forward translation and back translation of the original questionnaire into Colombian from Italian (see Appendix). The goodness of the translation was judged by the degree of overlap with the original version. This study was approved by the Ethical Committee of the Università Cattolica del Sacro Cuore, Milano (Italy). One of the researchers received the Protecting Human Research Participants certification by the National Institutes of Health (NIH) Office of Extramural Research.

\section{Data Analysis}

Confirmatory Factor Analysis (CFA) was used to test the fit of the two-factor correlated model (Aschieri \& Durosini, 2015) in the Colombian and Italian samples. Missing data were calculated using the Expectation-Maximization technique.

Then, an analysis of Measurement Invariance (MI) was conducted in order to determine if and how the structure of the SCAI differed between the Colombian and Italian samples. MI analyses were realized by increasingly restrictive models: (a) Model 1 tested Configural Invariance, assessing if the factor structure was the same across groups; (b) Model 2 tested the Metric Invariance by constraining the factor loading to be equal across groups; (c) Model 3 tested Scalar Invariance by constraining the loading and the intercepts of individual items to be the same across groups.

Also, both Cronbach's alpha and Ordinal Alpha via Empirical copula (Bonanomi, Nai Ruscone, \& Osmetti, 2012; Bonanomi, Cantaluppi, Nai Ruscone, \& Osmetti, 2015) and Pearson's correlations were run in order to determine the reliability and the validity of the SCAI in the Colombian context. Statistical analyses were conducted using SPSS AMOS 22.0, SPSS Statistical Software 20.0 and $R$ Software.

\section{Instruments}

The SCAI Scale was correlated with instruments already translated, adapted for the use with Spanish-speaking participants or developed in Latin-American context.

Table 1 Socio-demographic Analysis of the Colombian Sample $(n=170)$ and the Italian Sample $(n=195)$

\begin{tabular}{|c|c|c|c|c|c|c|c|c|}
\hline \multirow{2}{*}{\multicolumn{2}{|c|}{ Descriptive Data }} & \multicolumn{2}{|c|}{ Colombian Sample $(n=170)$} & \multicolumn{2}{|c|}{ Italian Sample $(n=195)$} & \multirow[b]{2}{*}{$\chi^{2}$} & \multirow[b]{2}{*}{$d f$} & \multirow[b]{2}{*}{$p$} \\
\hline & & $n$ & $\%$ & $n$ & $\%$ & & & \\
\hline \multirow[t]{3}{*}{ Gender } & & & & & & .351 & 1 & .553 \\
\hline & Male & 56 & 32.9 & 70 & 35.9 & & & \\
\hline & Female & 114 & 67.1 & 125 & 64.1 & & & \\
\hline \multirow[t]{5}{*}{ Age } & & & & & & 5.766 & 3 & .124 \\
\hline & $18-25$ & 95 & 55.9 & 103 & 53.1 & & & \\
\hline & $26-35$ & 29 & 17.0 & 49 & 25.3 & & & \\
\hline & $36-45$ & 21 & 12.4 & 25 & 12.8 & & & \\
\hline & $45-65$ & 25 & 14.7 & 17 & 8.8 & & & \\
\hline \multirow[t]{4}{*}{ Occupation } & & & & & & 3.936 & 2 & .140 \\
\hline & Unemployed & 71 & 41.8 & 96 & 50 & & & \\
\hline & Blue Collar & 55 & 32.3 & 45 & 23.4 & & & \\
\hline & White Collar & 44 & 25.9 & 51 & 26.6 & & & \\
\hline
\end{tabular}

Note. Chi-square tests were used to assess group differences in gender, age, and occupation status. 
NEO-Five Factor Inventory (NEO-FFI; Costa \& McCrae, 1989; Costa \& McCrae, 1999). The NEO-FFI is a 60 -item self-report questionnaire that assesses personality through the broad domains of the five factor model: Openness, Extraversion, Agreeableness, Neuroticism, and Conscientiousness. Internal consistency (Cronbach's alpha) was .716 for Openness, .826 for Extraversion, .772 for Agreeableness, .829 for Neuroticism, and .858 for Conscientiousness.

Philadelphia Mindfulness Scale (PHLMS; Cardaciotto, Herbert, Forman, Moitra, \& Farrow, 2008; Tejedor et al., 2014). The PHLMS is a brief self-report questionnaire that evaluates mindfulness in adults through two key components: Awareness, and Acceptance. The first factor relates to the continuous operation of internal and external stimuli, and the second factor concerns the person's non-judgmental disposition towards one's experience. Internal reliability was measured for Awareness and Acceptance factors and revealed a good consistency (Cronbach's alpha equal to .786 and .832 , respectively).

Interest and Deprivation Scale (ID; Litman, 2008). The ID scale is a 10 -item self-report instrument that measures two specific dimensions of epistemic curiosity. The first factor is Interest (I-type curiosity) and it is related with how people enjoy learning new ideas, while the second factor is Deprivation (D-type curiosity) and it's concerns with the way in which people find solutions to specific problems. In the present study, the test shows a satisfactory internal consistency as Cronbach's alpha for Interest is .630 and for Deprivation is .687 .

Academic Motivation Scale (Escala de Motivación Académica, EMA; Vallerand et al., 1992; Stover, de la Iglesia, Rial Boubeta, \& Fernández, 2012). The EMA is a 27-item self-report questionnaire that allows to compare motivational and academic variables through seven items in order to understand their impact on learning and perceived competence. Factors' Cronbach's alpha were .569 for In- trinsic Motivation Towards Stimulating Experiences, .812 for Intrinsic Motivation Towards Achievement, .844 for Intrinsic Motivation Towards Knowledge, .562 for Extrinsic Motivation Identified, .811 for Extrinsic Motivation Introjected, .800 for Extrinsic Motivation Regulated Externally, and .819 for Amotivation.

Positive and Negative Affectivity Scale (PANAS; Watson, Clark, \& Tellegan, 1988; Moriondo, De Palma, Medrano, \& Murillo, 2012). The PANAS is a 20 -item scale that aims to evaluate the underlying structure of affective states through two factors (Positive Emotions and Negative Emotions). The instrument in this study showed good internal consistency (Cronbach's alpha equal to .814 for the first factor [Positive Emotions] and .908 for the second factor [Negative Emotions]).

Satisfaction With Life Scale (SWLS; Diener, Emmons, Larsen, \& Griffin, 1985). The SWLS is a brief self-report instrument that assess well-being. This scale is composed by 5 -items and showed a good internal consistency (Cronbach's alpha equal to .851).

\section{Results}

\section{Confirmatory Factor Analysis (CFA)}

CFA tested the fit of the two-factor correlated model of the SCAI Scale (Figure 1). Analyses were run for Colombian and Italian samples, separately. Results of CFA conducted on the Colombian sample showed an excellent fit $\left(\chi^{2}(13)=10.352, p\right.$ $=.665 ; \chi^{2} / \mathrm{df}=.796, \mathrm{GFI}=.982, \mathrm{CFI}=1.000, \mathrm{RMSEA}=.000$, $95 \% \mathrm{Cl}[.000 ; .062], S R M R=.037)$. In the same line, results of CFA conducted on the Italian sample revealed an excellent fit to the data $\left(\chi^{2}(13)=16.073, p=.245 ; \chi^{2} / \mathrm{df}=1.236\right.$, $\mathrm{GFI}=.978, \mathrm{CFI}=.981, \mathrm{RMSEA}=.035,95 \% \mathrm{CI}[.000 ; .083]$, $S R M R=.043)$.

Figure 1 Correlated structural model of the Colombian version of the SCAI.

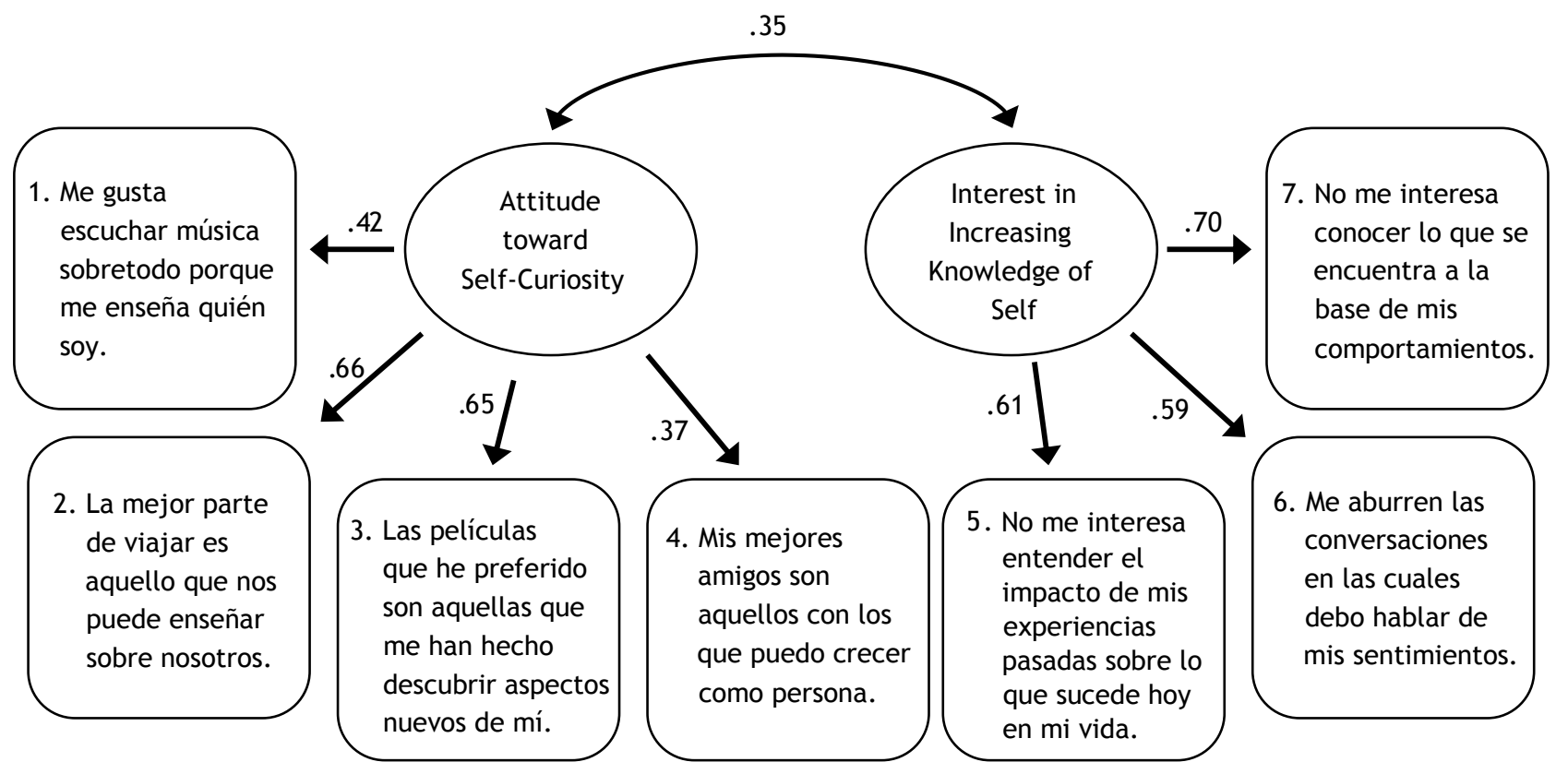

Note: Items 5, 6, and 7 were reversed. 


\section{Measurement Invariance Analysis (MI)}

Results of the Ml suggest that Model 1 provides an excellent fit to the data $\chi^{2}(26)=26.423 ; p=.440 ; \chi^{2} / \mathrm{df}=1.016$; RMSEA = .007; $90 \% \mathrm{Cl}$ [.000; .042]; CFI = .999; $\Delta \times 2=16.071$; $\Delta d f=13 ; p=.245$ ), indicating that the factorial structure is equivalent in Colombian and Italian subjects. Model 2 provides an excellent fit to the data as well $\left(\chi^{2}(31)=34.242\right.$; $p=.315 ; \chi^{2} / d f=1.105 ;$ RMSEA $=.017 ; 90 \% \mathrm{Cl}[.000 ; .044]$; $\mathrm{CFI}=.989 ; \Delta \times 2=23.890 ; \Delta d f=18 ; p=.159)$, indicating that the items factor loadings are equivalent between groups. Model 3, adding constrains to loadings and items intercepts, reveals significant differences between the two groups $\chi^{2}$ $(38)=82.058 ; p<.001 ; \chi^{2} / d f=2.159 ;$ RMSEA $=.057 ; 90 \% \mathrm{Cl}$ [.040; .073]; CFI $=.855 ; \Delta \chi^{2}=71.706, \Delta d f=25, p<.001$ ). These results suggest that levels of self-curiosity differ systematically between Italian and Colombian participants.

\section{Scale Reliability}

The internal consistency of the SCAI was calculated using both Cronbach's alpha and Ordinal Alpha via Empirical Copula Index (Bonanomi et al., 2012; Bonanomi et al., 2015). The latter is a modification of the Zumbo's Ordinal Alpha (Gadermann, \& Zeisser, 2007) useful to assess the reliability of polytomous ordinal response items. The Colombian version of the SCAl showed a Cronbach's alpha coefficients equal to .634 for the total scale and a coefficients equal to .600 and .664 for the Attitude toward Self-Curiosity and the Interest in Increasing Knowledge of Self factors. In the same line, Ordinal Alpha via Empirical Copula Index highlighted a coefficient equal to .645 for the total scale, and to .598 and .683 for the first factor Attitude toward Self-Curiosity and the second factor Interest in Increasing Knowledge of Self, respectively.

The inter-item correlation analysis revealed that Colombian and Italian samples had comparable coefficients for all the item of the SCAI (Table 2). The data suggested that the highest discrepancy between Colombians and Italians was .206 between Item 3 "Las películas que he preferido son aquellas que me han hecho descubrir aspectos nuevos de mí" and Item 2 "La mejor parte de viajar es aquello que nos puede enseñar sobre nosotros". Also, there is a discrepancy of .141 between Item 7 "No me interesa conocer lo que se encuentra a la base de mis comportamientos" and Item 6 "Me aburren las conversaciones en las cuales debo hablar de mis sentimientos".

The item-total correlation analysis revealed a significant contribution of each item of the SCAI to the Total Scale score (Table 3).

Regarding normality, Skewness and Kurtosis were in the range $+/-1.93$ and $+/-3.35$, respectively (Table 3). Curran, West and Finch (1996) stated that non-normality issues arise when Skewness exceeds the absolute value of 2.0 and/or Kurtosis exceeds the absolute value of 7.0 (p. 26). These thresholds are commonly adopted in the field of personality assessment, to make a decision on whether a mathematical transformation (e.g., log transformation) is or is not needed for a given variable (e.g., Giromini, Velotti, de Campora, Bonalume, \& Zavattini, 2012; Giromini et al., 2016).

\section{Scale Construct Validity}

In order to evaluate the construct validity of the scale, the Colombian version of the SCAI was correlated with other instruments validated with Spanish speaking groups. Table 4 shows the correlations between the Colombian version of the SCAI and all other instruments.

The SCAI Total scale and the NEO-FFI showed a moderate correlation in Openness $(r=.34, p<.001)$ and two small yet significant correlations with Extraversion and Agreeableness $(r=.20, p=.010 ; r=.15, p=.047$, respective(y). In particular, the first factor of the SCAI Scale, Attitude toward Self-Curiosity, showed a moderate correlation with

Table 2 Inter-item correlations coefficients in Colombian $(n=170)$ and Italian samples $(n=195)$

\begin{tabular}{|c|c|c|c|c|c|c|c|}
\hline Item & 1. & 2. & 3. & 4. & 5. & 6. & 7. \\
\hline $\begin{array}{l}\text { 1. Me gusta escuchar música sobretodo } \\
\text { porque me enseña quién soy }\end{array}$ & - & & & & & & \\
\hline $\begin{array}{l}\text { 2. La mejor parte de viajar es aquello que } \\
\text { nos puede enseñar sobre nosotros }\end{array}$ & $.235 / .208$ & - & & & & & \\
\hline $\begin{array}{l}\text { 3. Las películas que he preferido son } \\
\text { aquellas que me han hecho descubrir } \\
\text { aspectos nuevos de mí }\end{array}$ & $.316 / .319$ & $.422 / .216$ & - & & & & \\
\hline $\begin{array}{l}\text { 4. Mis mejores amigos son aquellos con } \\
\text { los que puedo crecer como persona }\end{array}$ & $.184 / .307$ & $.299 / .287$ & $.176 / .255$ & - & & & \\
\hline $\begin{array}{l}\text { 5. No me interesa entender el impacto } \\
\text { de mis experiencias pasadas sobre lo } \\
\text { que sucede hoy en mi vida }\end{array}$ & $.071 / .022$ & $.147 / .106$ & $.219 / .170$ & $-.031 / .119$ & - & & \\
\hline $\begin{array}{l}\text { 6. Me aburren las conversaciones en las } \\
\text { cuales debo hablar de mis sentimientos }\end{array}$ & $.058 / .023$ & $.181 / .142$ & $.153 / .064$ & $.099 / .100$ & $.346 / .324$ & - & \\
\hline $\begin{array}{l}\text { 7. No me interesa conocer lo que se encuentra } \\
\text { a la base de mis comportamientos }\end{array}$ & $.048 / .169$ & $.154 / .263$ & $.148 / .182$ & $.069 / .152$ & $.436 / .527$ & $.418 / .277$ & - \\
\hline
\end{tabular}

Note. Correlations regarding Colombian sample are placed to the left of the slash, those regarding Italian sample are placed to the right. Items 5, 6, and 7 were reversed. 
Table 3 Means, Standard Deviations (SD), descriptive statistics, item-total correlations, and Ordinal Alpha if item deleted in Colombian $(n=170)$ and Italian samples $(n=195)$

\begin{tabular}{|c|c|c|c|c|c|c|}
\hline Item & $M$ & $S D$ & Skewness & Kurtosis & $\begin{array}{c}\text { Item-total } \\
\text { correlations }\end{array}$ & $\begin{array}{l}\text { Ordinal Alpha } \\
\text { if item deleted }\end{array}$ \\
\hline $\begin{array}{l}\text { 1. Me gusta escuchar música sobretodo } \\
\text { porque me enseña quién soy }\end{array}$ & $3.027 / 3.410$ & $1.090 / 1.365$ & $.059 /-.529$ & $-.527 /-.889$ & $.258 / .286$ & $.635 / .571$ \\
\hline $\begin{array}{l}\text { 2. La mejor parte de viajar es aquello } \\
\text { que nos puede enseñar sobre nosotros }\end{array}$ & $3.635 / 3.974$ & $1.169 / 1.146$ & $-.600 /-.904$ & $-.373 / .018$ & $.426 / .343$ & $599 / .554$ \\
\hline $\begin{array}{l}\text { 3. Las películas que he preferido son } \\
\text { aquellas que me han hecho descubrir } \\
\text { aspectos nuevos de mí }\end{array}$ & $3.328 / 3.406$ & $1.154 / 1.338$ & $-.319 /-.462$ & $-.567 /-.830$ & $.423 / .343$ & $.597 / .549$ \\
\hline $\begin{array}{l}\text { 4. Mis mejores amigos son aquellos con } \\
\text { los que puedo crecer como persona }\end{array}$ & $3.818 / 4.405$ & $1.150 / .955$ & $-.748 /-1.859$ & $-.239 / 3.350$ & $.224 / .355$ & $.644 / .557$ \\
\hline $\begin{array}{l}\text { 5. No me interesa entender el impacto } \\
\text { de mis experiencias pasadas sobre lo } \\
\text { que sucede hoy en mi vida }\end{array}$ & $3.890 / 4.236$ & $1.122 / 1.238$ & $-.923 /-1.546$ & $.088 / 1.185$ & $.346 / .362$ & $.598 / .541$ \\
\hline $\begin{array}{l}\text { 6. Me aburren las conversaciones en } \\
\text { las cuales debo hablar de mis } \\
\text { sentimientos }\end{array}$ & $3.585 / 3.554$ & $1.226 / 1.422$ & $-.542 /-.501$ & $-.678 /-1.063$ & $.364 / .255$ & $.597 / .569$ \\
\hline $\begin{array}{l}\text { 7. No me interesa conocer lo que } \\
\text { se encuentra a la base de mis } \\
\text { comportamientos }\end{array}$ & $3.952 / 4.405$ & $1.112 / 1.063$ & $-.995 /-1.937$ & $.307 / 2.949$ & $.375 / .471$ & $.589 / .517$ \\
\hline
\end{tabular}

Note. Data regarding Colombian sample are placed to the left of the slash, those regarding Italian sample are placed to the right. Items 5,6 , and 7 were reversed.

Openness $(r=.37, p<.001)$, while the second factor of the SCAI Scale, Interest in Increasing Knowledge of Self, showed a small significant correlation with Extraversion $(r=.17$, $p=.029)$ and Agreeableness $(r=.16, p=.042)$.

Regarding the PHLMS, the SCAI Total scale showed a moderate correlation with Awareness $(r=.38, p<.001)$ and a negative and small correlation with Acceptance $(r=-.177$, $p=.021)$. The Attitude toward Self-Curiosity and the Interest in Increasing Knowledge of Self factors of the Colombian version of the SCAl showed moderate correlations with Awareness $(r=.37, p<.001 ; r=.21, p<.01$, respectively). Also, the Attitude toward Self-Curiosity factor showed a negative and small correlation with Acceptance $(r=-.18$, $p=.017)$.

In the ID Scale, Interest factor and Deprivation factor showed significant correlations with the SCAl Total scale $(r=.30, p<.01 ; r=.23, p<.01$, respectively). Also, Attitude toward Self-Curiosity SCAI factor showed significant correlations with Interest $(r=.32, p<.01)$ and Deprivation factors $(r=.27, p<.001)$. However, Interest in Increasing Knowledge of Self does not show significant correlation with the ID Scale.

The EMA showed significant correlations with the SCAI Total scale. Specifically, data showed positive correlation between SCAI Total score and Intrinsic Motivation Towards Stimulating Experiences $(r=.30, p<.01)$, Intrinsic Motivation Towards Achievement $(r=.24, p=.018)$, and Intrinsic Motivation Towards Knowledge $(r=.35, p<.001)$. The first factor of the SCAI correlated with Intrinsic Motivation Towards Stimulating Experiences $(r=.31, p<.01)$, with Intrinsic Motivation Towards Achievement $(r=.26, p<.01)$, and Intrinsic Motivation Towards Knowledge $(r=.24, p=.016)$. The second factor of the SCAl correlated only with Intrinsic Motivation Towards Knowledge $(r=.28, p<.01)$.

Also, the SCAI Total scale and the Attitude toward Self-
Curiosity showed positive and significant correlations with the Positive Emotions of PANAS Scale $(r=.23, p=.020 ; r=$ $.28, p<.01)$. However, no statistical significant correlations were found between SCAI factors and Negative Emotions.

Finally, no significant correlations were found between the SCAI Total scale and the SWLS Total scale, nor between the SCAl's individual factors and the SWLS Total scale.

\section{Discussion}

This paper aimed to assess the psychometric properties of the Colombian translation of the SCAI. The data show that the two-factor structure of the SCAI fits the data from Colombian subjects. CFA and MI analyses suggest that participants with different culture conceptualize curiosity about new aspects of their psychological functioning similarly. Configural (Model 1) and Metric Invariance (Model 2) revealed that each factor is associated with identical item sets across groups and with equal corresponding factor loadings across groups. Instead, Scalar Invariance (Model 3) was not satisfied. Colombian and Italian subjects could not be meaningfully compared and contrasted on the dimension of self-curiosity.

Analyses run on the construct validity of the SCAI confirm previous findings (Aschieri \& Durosini, 2015) in which self-curiosity appeared, as a whole and in its first factor, moderately correlated with the extent to which people are cognitively curious, innovative, and perceptive. The results suggest that self-curiosity is related to a person's efforts to perceive internal impulses and make use of them in their behaviors. This study also supports the hypothesis described in Aschieri and Durosini (2015), regarding the role of dissatisfaction about one's own personality and curiosity. In fact, the negative correlations between the attitude that people have to explore own inner world and the Acceptance factor 
Table 4 Correlation coefficients between Colombian version of the SCAI, and NEO-FFI, PHLMS, ID, EMA, PANAS, and SWLS

\begin{tabular}{|c|c|c|c|}
\hline & $\begin{array}{l}\text { SCAI - Attitude toward } \\
\text { Self-Curiosity }\end{array}$ & $\begin{array}{l}\text { SCAI - Interest in Increasing } \\
\text { Knowledge of Self }\end{array}$ & $\begin{array}{l}\text { SCAI - Total } \\
\text { Scale }\end{array}$ \\
\hline & $r$ & $r$ & $r$ \\
\hline \multicolumn{4}{|l|}{ NEO-FFI } \\
\hline Openness & $.365^{* *}$ & .148 & $.336^{* *}$ \\
\hline Extraversion & .142 & $.167^{*}$ & $.197^{*}$ \\
\hline Agreeableness & .086 & $.157^{*}$ & $.153^{*}$ \\
\hline Neuroticism & .088 & -.072 & .017 \\
\hline Conscientiousness & .003 & .031 & .021 \\
\hline \multicolumn{4}{|l|}{ PHLMS } \\
\hline Awareness & $.373^{* *}$ & $.213^{* *}$ & $.383^{* *}$ \\
\hline Acceptance & $-.183^{*}$ & -.087 & $-.177^{*}$ \\
\hline \multicolumn{4}{|l|}{ ID } \\
\hline Interest & $.315^{* *}$ & .144 & $.302^{* *}$ \\
\hline Deprivation & $.269^{* *}$ & .079 & $.232^{* *}$ \\
\hline \multicolumn{4}{|l|}{ EMA } \\
\hline Intrinsic Motivation Towards Stimulating Experiences & $.305^{* *}$ & .136 & $.297^{* *}$ \\
\hline Intrinsic Motivation Towards Achievement & $.259^{* *}$ & .092 & $.236^{*}$ \\
\hline Intrinsic Motivation Towards Knowledge & $.241^{*}$ & $.282^{* *}$ & $.349^{* *}$ \\
\hline Extrinsic Motivation Identified & .097 & .062 & .107 \\
\hline Extrinsic Motivation Introjected & .119 & -.032 & .060 \\
\hline Extrinsic Motivation Regulated Externally & -.005 & .009 & .003 \\
\hline Amotivation & -.058 & -.083 & -.094 \\
\hline \multicolumn{4}{|l|}{ PANAS } \\
\hline Positive Emotions & $.279^{* *}$ & .066 & $.233^{*}$ \\
\hline Negative Emotions & .169 & .087 & .170 \\
\hline \multicolumn{4}{|l|}{ SWLS } \\
\hline Total Scale & .155 & .111 & .178 \\
\hline
\end{tabular}

Note. ${ }^{*} p<.05,{ }^{* *} p<.01$.

suggests that dissatisfaction with one's own psychological features may motivate to understand oneself better. Also, correlational analyses highlight that that the attitude toward self-exploration is connected both with the intrinsic reward for new discoveries (Interest) and with extrinsically regulated concerns about their usefulness (Deprivation). Results also suggested that the more people are open to discover their inner experiences, the more they are also internally motivated to seek stimulating experiences and executing behaviors by own choice. Finally, the data revealed that self-curiosity is related to the degree to which a person feels enthusiastic, active, and alert, and self-curiosity is not significantly related with a person's perception of life satisfaction.

\section{Conclusions}

Decades of studies have focused on trying to explain human curiosity and curious behaviors, identifying different theoretical perspectives. Curiosity has been also addressed in Latin-American countries stressing its importance in aca- demic achievement, personal development, self-awareness, mental health and social relationships. Recently, a new kind of curiosity -namely self-curiosity- was defined and measured through a brief self-report scale called Self-Curiosity Attitude-Interest Scale (SCAI). This instrument assesses the disposition that people have about exploring their inner world and their psychological functioning. This paper sought to validate the SCAI Scale in the Colombian context. Confirmatory Factor Analysis showed that the factor structure of the SCAI Scale is adequate in Colombian subjects. Also, Measurement Invariance Analysis highlighted that self-curiosity is conceived similarly in Colombia and in Italy and that in both countries the items that measure self-curiosity factors have similar weights on their total scores.

However, our results suggest that Colombian and Italian subjects have stable and systematic differences in the levels of self-curiosity that hinders the possibility of a direct comparison between countries. Despite the two samples were matched for relevant socio-economic features such as gender, age and occupation, the comparatively small size of the sample and the presence of uncontrolled differences (such as 
social desirability, or ease with completing online surveys) in the two groups of respondents should be addressed in further studies.

This paper presented also data on reliability and concurrent validity of the SCAI. Despite several authors recommend a coefficient of internal consistency of .700 as a safe benchmark for an ethical use of self-report scales, we believe that the internal scale consistency is acceptable and suggests a non-excessive homogeneity or overlapping items (Nunnally, 1978) - considering the SCAI small number of items (seven) and the impact of the number of items on alpha coefficient (John \& Benet-Martinez, 2000). The concurrent validity of the SCAI Scale was also evaluated against other psychological constructs such as general curiosity, big five personality traits, learning motivation, affect states and personal values. The results revealed that self-curiosity is related to openness and extraversion personality traits, to intrinsic motivation, to self-awareness and to motivational dispositions to modify personal experiences. In addition, people with higher self-curiosity tend to be more sociable, energetic, and to experience more positive emotions.

From a practical and clinical standpoint, the availability of a measure of self-curiosity is useful in different fields. Clinicians' curiosity for themselves and their psychological processes is key to keep their reflexivity and self-awareness alive (Aschieri, 2016). Measuring self-curiosity helps the therapist in pacing different interventions with different kinds of clients (Frackowiak, Fantini, \& Aschieri, 2015). The assessment of self-curiosity helps therapists to evaluate clients' desire to understand and discover through treatment new things about themselves, and select, on such bases, the more appropriate therapeutic approach and psychological techniques with the client, thereby modulating the timing of interventions based on the clients' availability to understand themselves better (Durosini, Tarocchi, \& Aschieri, 2017) and on the presence of adequate emotional regulation skills to allow new information about the self to be beneficial (Tarocchi, Aschieri, Fantini, \& Smith, 2013).

Self-curiosity can impact on the availability of families to process new insights about their dynamics (Aschieri, Fantini, \& Bertrando, 2012; Smith, Handler, \& Nash, 2010). Finally, self-curiosity seems a promising variable to consider in order to increase outside-laboratory implementation of innovative online and computer-based treatments (Fleming et al., 2016).

\section{Appendix}

1. Me gusta escuchar música sobretodo porque me enseña quién soy [Mi piace ascoltare la musica soprattutto perché mi insegna come sono fatto].

2. La mejor parte de viajar es aquello que nos puede enseñar sobre nosotros [La parte migliore del viaggiare è ciò che può insegnarci su di noi].

3. Las películas que he preferido son aquellas que me han hecho descubrir aspectos nuevos de mí [I film che ho preferito sono quelli che mi hanno fatto scoprire aspetti nuovi di me].

4. Mis mejores amigos son aquellos con los que puedo crecer como persona [I miei migliori amici sono quelli con cui posso crescere come persona].
5. No me interesa entender el impacto de mis experiencias pasadas sobre lo que sucede hoy en mi vida [Non mi interessa capire l'impatto che le mie esperienze passate hanno su quello che succede oggi nella mia vita].

6. Me aburren las conversaciones en las cuales debo hablar de mis sentimientos [Mi annoiano i discorsi in cui devo parlare dei miei sentimenti].

7. No me interesa conocer lo que se encuentra a la base de mis comportamientos [Non mi interessa conoscere ciò che sta alla base dei miei comportamenti].

\section{Aknowledgement}

This research originated from the final exam dissertation of three authors, in the framework of a Double Title Agreement between Università Cattolica del Sacro Cuore, Milan, Italy and Universidad La Sabana, Bogotá, Colombia.

\section{References}

Arango, A. \& Vanegas, C. V. (2014). Efectos del consumo de alcohol vía vaginal en adolescentes en cuatro colegios de la ciudad de Medellín, Colombia. Revista Chilena de Obstetricia y Ginecologia, 79(4), 283287. http://dx.doi.org/10.4067/S0717-75262014000400006

Aschieri, F. (2016). Shame as a cultural artifact: A call for self-awareness and reflexivity in personality assessment. Journal of Personality Assessment, 98(6), 567-575. http://dx.doi.org/10.1080/0 0223891.2016.1146289

Aschieri, F., \& Durosini, I. (2015). Development of the Self-Curiosity Attitude-Interest Scale. Testing, Psychometrics, Methodology in Applied Psychology, 22(3), 326-346. http://dx.doi.org/10.4473/ TPM22.3.2

Aschieri, F., De Saeger, H., \& Durosini, I. (2015). L’Évaluation Thérapeutique et collaborative: Preuves empiriques. Pratiques Psychologiques, 21, 307-317. http://dx.doi.org/10.1016/j.prps.2015.09.005

Aschieri, F., Durosini, I., Locatelli, M., Gennari, M. L., \& Smith, J. D. (2016). Factor structure invariance and discriminant validity of the Self-Curiosity Attitude-Interest Scale. Testing, Psychometrics, Methodology in Applied Psychology, 23, 139-148. http://dx.doi.org/10.4473/TPM23.2.1

Aschieri, F., Fantini, F., \& Bertrando, P. (2012). Therapeutic assessment with children in family therapy. Australian and New Zealand Journal of Family Therapy, 33, 285-298. http://dx.doi. org/10.1017/aft.2012.37

Beaton, D. E., Bombardier, C., Guillemin, F., \& Ferraz, M. B. (2000). Guidelines for the process of cross-cultural adaptation of self-report measures. Spine, 25, 3186-3191.

Berlyne, D. E. (1949). Interest as a psychological concept. British Journal of Psychology, 39, 184-185.

Berlyne, D. E. (1950). Novelty and curiosity as determinants of exploratory behavior. British Journal of Psychology, 41, 68-50.

Berlyne, D. E. (1954), A Theory of Human Curiosity. British Journal of Psychology General Section, 45, 180-191.

Berlyne, D. E. (1960). Conflict, arousal and curiosity. New York, NY: McGraw-Hill.

Berlyne, D. E. (1966). Curiosity and exploration. Science, 153, 25-33.

Berlyne, D. E. (1967). Arousal and reinforcement. In D. Levine (Ed.), Nebraska symposium on motivation (pp. 1-110). Lincoln: University of Nebraska Press.

Bonanomi A., Nai Ruscone M., \& Osmetti S. A. (2012). Reliability measurement for polytomous ordinal items: the empirical polychoric ordinal Alpha. Quaderni di Statistica, 14, 53-56.

Bonanomi, A., Cantaluppi, G., Nai Ruscone, M., \& Osmetti, S. A. (2015). A new estimator of Zumbo's Ordinal Alpha: a copula approach. Quality \& Quantity, 49(3) 941-953. 
Cardaciotto, L., Herbert, J. D., Forman, E.M., Moitra, E., \& Farrow, V. (2008). The assessment of present-moment awareness and acceptance: The Philadelphia Mindfulness Scale. Assessment, 15, 204-23. http://dx.doi.org/10.1177/1073191107311467

Costa, P. T., \& McCrae, R. R. (1989). NEO PI/FFI manual supplement for use with the NEO Personality Inventory and the NEO-Five Factor Inventory. Odessa: FL Psychological Assessment Resources.

Costa, P. T., \& McCrae, R. R. (1999). Inventario NEO reducido de cinco factores (NEO-FFI): manual profesional. Madrid, España: TEA Ediciones.

Curran, P. J., West, S. G., \& Finch, J. F. (1996). The robustness of test statistics to nonnormality and specification error in confirmatory factor analysis. Psychological methods, 1(1), 16-29

Dember, W. N. (1956). Response by the rat to environmental change. Journal of Comparative and Physiological Psychology, 49 (1), 93-95. http://dx.doi.org/10.1037/h0045411

Diener, E., Emmons, R., Larsen, R., \& Griffin, S. (1985). The Satisfaction with Life Scale. Journal of Personality Assessment, 49(1), 71-75. doi: 10.1207/s15327752jpa4901_ 13

Durosini, I., Tarocchi, A., \& Aschieri, F. (2017). Therapeutic assessment with a client with Persistent Complex Bereavement Disorder: A single- case time-series design. Clinical Case Studies, 16(4), 295-312. http://dx.doi.org/10.1177/1534650117693942

Finn, S. E. (2007). In our clients' shoes: Theory and techniques of therapeutic assessment. Mahwah, NJ: Earlbaum.

Fleming, T. M., de Beurs, D., Khazaal, Y., Gaggioli, A., Riva, G., Botella, C., ... Riper, H. (2016). Maximizing the impact of e-Therapy and Serious Gaming: Time for a paradigm shift. Frontiers in Psychiatry. 7, 65. http://dx.doi.org/10.3389/fpsyt.2016.00065

Fowler, H. (1966). Curiosity and exploratory behavior. New York, NY: Macmillan.

Frackowiak, M., Fantini, F., \& Aschieri, F. (2015). L'évaluation thérapeutique: description de quatre modèles. Pratiques Psychologiques, 21(4), 319-330. http://dx.doi.org/10.1016/j.prps.2015.09.006

Gálvez-Nieto, J. L., Salvo, S., Pérez-Lucoc, R., Hederich, C., \& Trizano-Hermosilla, I. (2017). Invarianza factorial del Cuestionario para Evaluar Clima Social del Centro Escolar en estudiantes chilenos y colombianos. Revista Latinoamericana de Psicología, 49(2), 119-127. http://dx.doi.org/10.1016/j.rlp.2016.09.003

García, G. M. P., \& Valdez, R. Á. (2017). Pros, contras, resilencia y motivaciones de consumo de alcohol y tabaco en jóvenes de preparatoria del sur de Sinaloa [Pros, Cons, Resilience and Motivation of alcohol consumption and snuff of the high school of south of Sinaloa]. Revista Conjeturas Sociológicas, 4(11), 91-112.

Giromini, L., Morese, R., Salatino, A., Di Girolamo, M., Viglione, D. J., \& Zennaro, A. (2016). Rorschach Performance Assessment System (R-PAS) and vulnerability to stress: A preliminary study on electrodermal activity during stress. Psychiatry research, 246, 166-172.

Giromini, L., Velotti, P., de Campora, G., Bonalume, L., \& Cesare Zavattini, G. (2012). Cultural adaptation of the difficulties in emotion regulation scale: Reliability and validity of an Italian version. Journal of Clinical Psychology, 68(9), 989-1007.

Gómez-Lugo, M., Espada, J. P., Morales, A., Marchal-Bertrand, L., Soler, F., \& Vallejo-Medina, P. (2016). Adaptation, validation, reliability and factorial equivalence of the Rosenberg Self-Esteem Scale in Colombian and Spanish Population. The Spanish Journal of Psychology, 19, 1-12. http://dx.doi.org/10.1017/sjp.2016.67

Harlow, H. F. (1950). Learning and satiation of response to intrinsically motivated complex puzzle performance by monkeys. Journal of Comparative and Physiological Psychology, 40, 289294. http://dx.doi.org/10.1037/h0058114

Hebb, D. O. (1955). Drives and the C. N. S. (Conceptual Nervous System). Psychological Review, 62, 243-254. http://dx.doi. org/10.1037/h0041823
John, O. P. \& Benet-Martínez, V. (2000). Measurement, scale construction, and reliability. In H.T. Reis \& C.M. Judd (Eds.), Handbook of research methods in social and personality psychology (pp. 339-369). New York, NY: Cambridge University Press.

Kashdan, T. B., \& Fincham, F. D. (2004). Facilitating curiosity: A social and self-regulatory perspective for scientifically based interventions. In P. A. Linley \& S. Joseph (Ed.), Positive psychology in practice (pp. 482-503). New Jersey, NJ: Wiley.

Leuba, C. (1955). Toward some integration of learning theories: The concept of optimal stimulation. Psychological Reports, 1(1), 27-33.

Litman, J. A. (2005). Curiosity and the pleasures of learning: Wanting and liking new information. Cognition and Emotion, 19(6), 793-814. http://dx.doi.org/10.1080/02699930541000101

Litman, J. A. (2008). Interest and deprivation factors of epistemic curiosity. Personality and Individual Differences, 44(7), 15851595. http://dx.doi.org/10.1016/j.paid.2008.01.014

Litman, J. A. \& Jimerson, T. L. (2004). The measurement of curiosity as a feeling of deprivation. Journal of Personality Assessment, 82(2), 147-157. http://dx.doi.org/10.1207/s15327752jpa8202_3

Litman, J. A., \& Silvia, P. J. (2006). The latent structure of trait curiosity: Evidence for interest and deprivation curiosity dimensions. Journal of Personality Assessment, 86(3), 318-328. http://dx.doi.org/10.1207/s15327752jpa8603_07

Loewenstein, G. (1994). The psychology of curiosity: A review and reinterpretation. Psychological Bulletin, 116(1), 75-98.

Lopez, S. J., \& Snyder, C. R. (Eds.). (2009). Oxford handbook of positive psychology (2nd ed.). New York, NY: Oxford University Press.

Matsumoto, D. R. (Ed.). (2001). The Handbook of Culture and Psychology. Oxford University Press.

Moriondo, M., De Palma, P., Medrano, L., \& Murillo, P. (2012). Adaptación de la Escala de Afectividad Positiva y Negativa (PANAS) a la población de Adultos de la ciudad de Córdoba: análisis psicométricos preliminares. Universitas Phychologica, 11(1), 187-196.

Nunnally, J. C. (1978). Psychometric theory (2nd ed.). New York, NY: McGraw-Hill.

Ruiz, P. G., Rosado, A. F. B., \& Galisteo, R. P. R. (2015). Validación de la versión reducida del CECASDEP en usuarios de servicios deportivos. Suma Psicológica, 22(2), 78-85. http://dx.doi.or$\mathrm{g} / 10.1016 / \mathrm{j}$. sumpsi.2015.08.001

Sánchez, M. (2007). Identificacion de estrategias para la formación de investigadores de la escuela. Studiositas, 2(2), 20-29.

Sánchez, R. O., Méndez, X., \& Garber, J. (2009). La promoción de la curiosidad de los estudiantes para participar de un programa preventivo. Anuario de Psicología Clínica y de la Salud, 5, 29-39.

Smith, J. D., Handler, L., \& Nash, M. R. (2010). Therapeutic assessment for preadolescent boys with oppositional defiant disorder: A replicated single-case time-series design. Psychological Assessment, 22, 593-602. http://dx.doi.org/10.1037/a0019697

Soler, F., Gómez-Lugo, M., Espada, J. P., Morales, A., Sierra, J. C., Marchal-Bertrand, L., \& Vallejo-Medina, P. (2016). Adaptation and validation of the Brief Sexuality Scale in Colombian and Spanish Populations. International Journal of Psychology and Psychological Therapy, 16(3), 343-356.

Spielberger, C. D., \& Starr, L. M. (1994). Curiosity and exploratory behavior. In H. F. O'Neil, Jr., \& M. Drillings (Eds.). Motivation: Theory and research (pp. 221-243). Hillsdale, NJ: Lawrence Erlbaum.

Stover, J, B., De la Iglesia, G., Rial Boubeta, A., \& Fernández, M. (2012). Academic Motivation Scale: adaptation and psychometric analysis for high school and college students. Psychology Research and Behavior Management, 5, 71-83. http://dx.doi. org/10.2147/PRBM.S33188 
Tarocchi, A., Aschieri, F., Fantini, F., \& Smith, J. D. (2013). Therapeutic assessment of complex trauma: A single-case time-series study. Clinical Case Studies, 12, 228-245. http://dx.doi. org/10.1177/1534650113479442.

Tejedor, R., Feliu-Soler, A., Pascual, J., Cebolla, A., Portella, M., Trujols, J. \& Soler, J. (2014). Propiedades psicométricas de la versión española de la Philadelphia Mindfulness Scale. Revista de Psiquiatría y Salud Mental, 7(4), 157-165. http://dx.doi.org/10.1016/j.rpsm.2014.04.001

Trujillo, A. M. \& Flòrez, I. A. (2013). Consumo de alcohol en los adolescentes de Chía y su percepción del consumo y de la permisividad parental frente al uso de sustancias. Revista Colombiana de Psicología, 22, 41-57.

Vallejo-Medina, P., Marchal-Bertrand, L., Gómez-Lugo, M., Espada, J. P., Sierra, J. C., Soler, F., ... Morales, A. (2016). Adaptation and validation of the Brief Sexual Opinion Survey (SOS) in a Colombian Sample and Factorial Equivalence with the Spanish Version. PLoS ONE, 11(9): e0162531. http://dx.doi.org/10.1371/ journal.pone. 0162531

Vallerand, R. J., Pelletier, L. G., Blais, M. R., Briére, N. M., Senécal, C., \& Valliéres, E. F. (1992). The academic motivation scale: A measure of intrinsic, extrinsic, and amotivation in education. Educational and Psychological Measurement, 52, 1003-1019.
Van de Vijver, F. (2001). Psychologie en de multiculturele samenleving [Psychology and the multicultural society]. Tilburg University.

Wanden-Berghe, R.G., Sanz-Valero, J., \& Wanden-Berghe, C. (2011). The application of mindfulness to eating disorders treatment: A systematic review. Eating Disorders: The Journal of Treatment \& Prevention, 19, 34-48. http://dx.doi.org/10.108 $0 / 10640266.2011 .533604$

Watson, D., Clark, L. A., \& Tellegan, A. (1988). Development and validation of brief measures of positive and negative affect: The PANAS scales. Journal of Personality and Social Psychology, 54(6), 1063-1070.

Zumbo, B. D., Gadermann, A. M., \& Zeisser, C. (2007). Ordinal versions of coefficients alpha and theta for Likert rating scales. Journal of modern applied statistical methods, 6(1), 21-29. http://dx.doi.org/10.22237/jmasm/1177992180 